\title{
STRATEGI SOSIALISASI MIGRASI SISTEM PENYIARAN ANALOG KE DIGITAL DI JAWA TENGAH
}

\author{
Made Dwi Adnjani ${ }^{1}$, Mubarok $^{2}$ \\ Prodi Ilmu Komunikasi Fakultas Bahasa dan Ilmu Komunikasi \\ Universitas Islam Sultan Agung (UNISSULA) \\ Jl. Kaligawe Raya Km. 4, Terboyo Kulon, Genuk, Kota Semarang, Jawa Tengah 50112. \\ Telp. (024) 6583584 \\ Email : made@unissula.ac.id ${ }^{1}$, mubarok@unissula.ac.id ${ }^{2}$
}

\begin{abstract}
The purpose of this research has described the development, analyzing the communications strategy tongue and strategies appropriate to socialization migration to analog to digital in central Java. The methodology uses deskripstive qualitative. Engineering data collection is done interviews with 200 the informant located in four areas namely Semarang, Magelang, Purwokerto, and Pekalongan. The method of was used in this research is qualitative descriptive. The technique of data collection was carried out in-depth interviews with 200 people an informant who are spread in four areas namely Semarang the capital city of, Magelang of Central Java, Purwokerto, and Pekalongan. The data analysis was undertaken using analysis phase of strategic communication which includes formative research, strategy, research, and evaluation tactic. The research results show a majority of residents central java did not know plan migration analog to digital to.This condition is a challenge to plan the communications strategy proper according to the conditions in central java so that the migration can run well and benefit all parties. Certainty roadmap migrations plenary will ease the preparation of the communications strategy. The contribution of this research is to provide communication strategy of socialization of digital broadcast system in Central Java.
\end{abstract}

Keywords: socialization, digitization, broadcasting, Central Java

\begin{abstract}
Abstrak
Penelitian ini bertujuan untuk mendiskripsikan perkembangan sosialisasi, menganalisa strategi komunikasi yang digunakan dan merumuskan strategi yang tepat untuk proses sosialisasi migrasi TV analog ke digital di Jawa Tengah. Metode penelitian ini menggunakan deskripstif kualitatif. Teknik pengumpulan data dilakukan wawancara mendalam kepada 200 orang informan yang tersebar di empat daerah yaitu Semarang, Magelang, Purwokerto dan Pekalongan. Tahap analisis data dilakukan dengan menggunakan analisis fase penyusunan komunikasi strategis yang meliputi formative research (riset formatif), strategy, tactic dan evaluation research. Hasil penelitian menunjukkan mayoritas masyarakat Jawa Tengah belum mengetahui rencana migrasi TV analog ke digital. Kondisi ini menjadi tantangan untuk merencanakan strategi komunikasi yang tepat sesuai kondisi di Jawa Tengah sehingga proses migrasi bisa berjalan dengan baik dan menguntungkan semua pihak. Kepastian peta jalan migrasi yang paripurna akan memudahkan penyusunan strategi komunikasi. Kontribusi penelitian ini berupa penemuan model pemanfaatan media di Jawa Tengah.
\end{abstract}

Kata kunci : sosialisasi, digitalisasi, penyiaran, Jawa Tengah

\section{Pendahuluan}

Proses migrasi penyiaran televisi analog ke penyiaran televisi digital adalah keniscayaan seiring perkembangan teknologi. Jumlah penduduk Indonesia mencapai lebih dari 200 juta jiwa. Dengan asumsi separuh dari mereka memiliki televisi di rumahnya maka ada sekitar 100 juta televisi di Indonesia.
Jumlah ini merupakan pasar yang potensial untuk industri penyiaran digital. Basis pemirsa yang besar menjadi potensi ideal pemasukan secara ekonomi. Televisi digital memiliki beragam keunggulan diantaranya kualitas penyiaran lebih baik dan frekuensi yang bisa dipakai banyak saluran. 
Sistem jaringan TV digital untuk akses televisi di rumah diarahkan menjadi layanan multimedia. Artinya layanan ini bisa sekaligus untuk keperluan telefoni, akses data internet, juga siaran televisi dengan kualitas gambar yang semakin mendekati realita melalui pesawat $T V$-Ultra High Definition. Perkembangan layanan ini biasa disebut dengan konsep "extended home", dimana para pengguna bisa menikmati akses berbagai konten multimedia (data teks, suara, audio dan video). Selain itu, layanan TV digital tidak lagi hanya bersifat fixed access, tetapi juga mobile access yang bisa digunakan kapan saja, di mana saja hanya dengan menggunakan satu terminal saja (Budiharto dkk, 2007).

Berikut adalah gambar klasifikasi layanan dan aplikasi yang mungkin dikembangkan dalam layanan tv digital.
Penerapan penyiaran TV Digital secara teknologi tidaklah mengharuskan pemirsa untuk membeli TV baru yang menggunakan teknologi digital. Masyarakat cukup menambahkan perangkat set-top box untuk menstransmisikan sinyal digital dari pemancar sehingga pesawat TV tersebut mampu menerima sinyal digital.

Di berbagai negara siaran televisi analog sudah dihentikan dan beralih ke penyiaran televisi digital. Di Eropa, Amerika, dan Jepang, migrasi ke sistem penyiaran TV digital sudah dimulai sejak beberapa tahun yang lalu. Di Jerman, proyek ini telah dimulai sejak 2003 di kota Berlin dan 2005 di Munich. Pada akhir 2005 di Inggris telah dilakukan percobaan untuk mematikan beberapa penyiaran TV analog. Di Amerika Serikat, Kongres bahkan telah memberikan mandat penghentian penyiaran

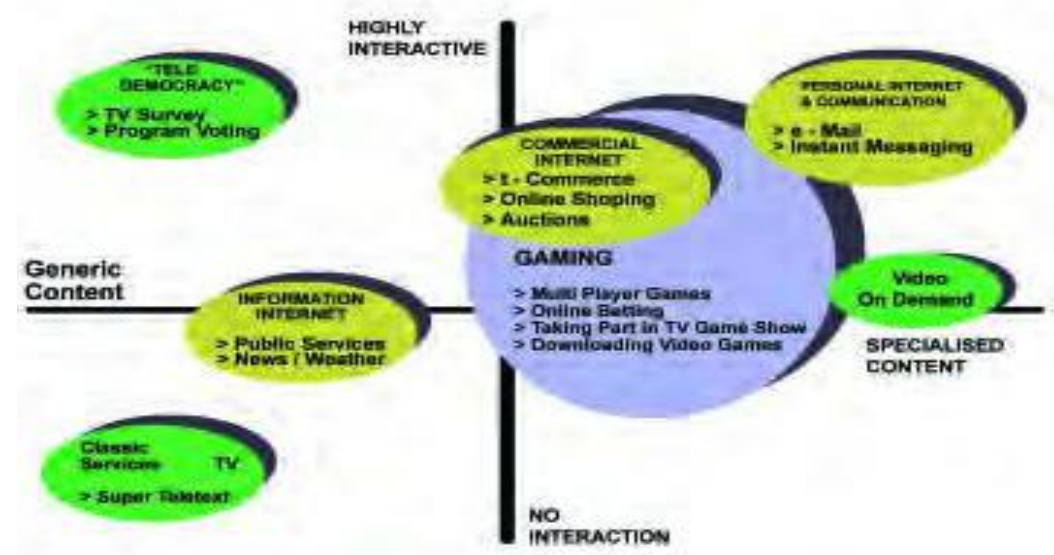

Gambar 1, Klasifikasi layanan dan aplikasi.

Sumber : Spieker, 2001 dalam Budiharto dkk, 2007.

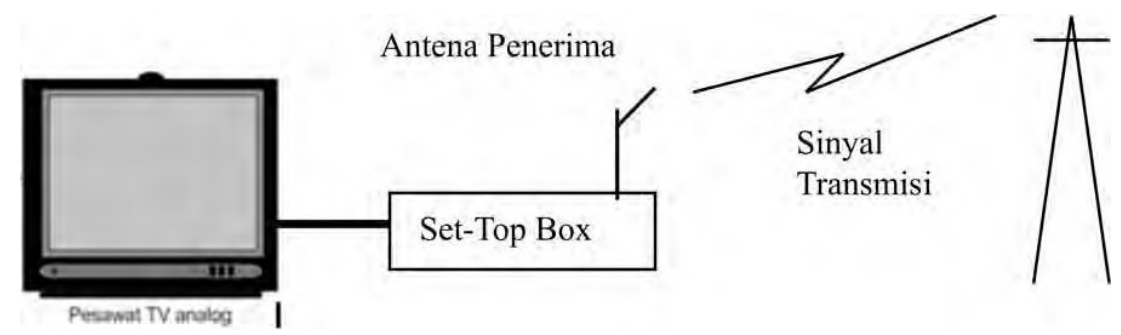

Gambar 2. Proses Penerimaan Penyiaran TV Digital Sumber: Budiarto dkk, 2007. 
TV analog secara total (switched off) pada tahun 2009. Indonesia sebagai anggota International Telecommunication Union (ITU) menargetkan pada tahun 2018 sudah bermigrasi ke penyiaran digital.

Pengembangan TV digital di Indonesia bukanlah hal baru. Sejak tahun 2004 di bawah koordinasi Tim Nasional Migrasi Televisi dan Radio dari Analog ke Digital, telah dilakukan sejumlah kajian terhadap implementasi penyiaran TV digital. Serangkaian diskusi, seminar, workshop dan lokakarya yang melibatkan tenaga ahli di bidang penyiaran TV digital dari beberapa penjuru dunia telah dilakukan. Bahkan uji coba siaran TV digital telah dilakukan sejak pertengahan tahun 2006 dengan menggunakan channel 34 UHF untuk standar DVB-T dan ch 27 UHF untuk standar T-DMB (Budiarto dkk, 2007).

Tolak ukur keberhasilan proses migrasi ini ditandai dengan semakin tingginya manfaat yang bisa diraih oleh masyarakat Indonesia. Artinya proses migrasi ini tidak boleh hanya menguntungkan pihak tertentu seperti industri televisi, piranti elektornik, pemerintah. Proses migrasi ini harus membawa manfaat bagi masyarakat seutuhnya sehingga tidak ada yang dirugikan. Untuk itu diperlukan pemahaman yang utuh terhadap proses ini sehingga masyarakat memahami proses digitalisasi ini. Sosialisasi dan edukasi diperlukan agar masyarakat memahami keuntungan dan kerugian proses migrasi termasuk memahami langkah apa yang harus mereka lakukan sehingga tidak menjadi korban dari perubahan teknologi penyiaran.

Ketika migrasi analog ke digital di Indonesia sudah mulai berlangsung semestinya sosialisasi yang dilakukan oleh pemerintah bisa lebih banyak dan merata bagi masyarakat Indonesia. Migrasi penyiaran dari analog ke digital sebenarnya tidak hanya bisa dimaknai sebagai perpindahan teknologi saja, karena banyak permasalahan baru yang akan muncul dengan adanya migrasi ini sehingga sosialisasi yang maksimal dan pengkajian yang komprehensif adalah tugas utama pemerintah. Rianto dkk (2012:24) mengatakan bahwa persoalan digitalisasi penyiaran merupakan persoalan yang kompleks sehingga mestinya melibatkan perdebatan publik dan parlemen sebagai representasi rakyat yang menjadi pemilik sah frekuensi. Beberapa persoalan di Indonesia yang harus diselesaikan dalam tahapan migrasi adalah belum meratanya jangkauan televisi di setiap daerah. Setiap daerah yang bisa menerima siaran tv analog harus bisa menerima siaran tv digital setelah migrasi. Dibeberapa daerah masih sulit untuk menerima siaran analog sementara mereka punya hak yang sama untuk mendapatkan informasi dan mengakses media tv.

Ada beberapa hal mendasar yang harus dilakukan oleh masyarakat agar mereka bisa menikmati penyiaran digital: pertama: mereka harus memiliki piranti yang mampu menangkat siaran digital baik berupa tv digital maupun tv analog yang dipasang receiver digital. Kedua, apakah mereka diberikan ruang dalam proses penyiaran digital atau sekedar dipandang sebagai konsumen konten digital. Persoalan teknis bisa diselesaikan dengan menyediakan peralatan yang dibutuhkan, sementara 
persoalan pemerataan kesempatan dan akses dalam proses digitalisasi membutuhkan sosialisasi yang terencana.

Kehadiran TV Digital yang direncanakan pada tahun 2018 membutuhkan beragam persiapan. Setidaknya ada beberapa pihak yang menaruh kepentingan yaitu pemerintah, akademisi, dunia inndustri dan masyarakat pada umumnya. Kehadiran sebuah teknologi semestinya memberikan manfaat sebesarbesarnya bagi seluruh manusia. Hal ini penting agar teknologi tidak hanya menjadi kepentingan segelintir orang. Banyak kehadiran teknologi yang tidak sesuai dengan kebutuhan penggunanya sehingga justru lebih sering menimbulkan masalah daripada memberikan manfaat. Pola diseminasi teknologi yang bersifat top down seringkali hanya memandang dari kacamata pemangku kebijakan bukan kacamata penggunanya. Oleh karena itu dibutuhkan penelitian yang mampu memetakan audience habit (kebiasaan dari pengguna) hingga ke strategi sosialisasi dan komunikasi kebijakan migrasi penyiaran analog ke digital di Indonesia.

Di dalam draft RUU Penyiaran tentang batas akhir penyiaran analog atau yang sering disebut sebagai Analog Switch off (ASO) dijelaskan pada pasal 15. Draft pasal 15 menyebutkan, "batas akhir penggunaan teknologi analog lembaga penyiaran jasa penyiaran televisi adalah 3 tahun setelah undang-undang penyiaran ini diundangkan". Pada wilayah tertentu yang memiliki kesiapan infrastruktur bisa dipercepat proses migrasinya. Beberapa wilayah seperti DKI Jakarta, Jawa Barat, Jawa Tengah, Jawa Timur, Yogyakarta, Bali menjadi prioritas migrasi karena memiliki kesiapan infrastruktur yang memadai. Kotakota besar di beberapa propinsi tersebut akan mengawali proses migrasi lebih cepat daripada daerah lainnya.

Di Jawa Tengah beberapa kota yang memiliki kesiapan infrastruktur untuk migrasi akan menjadi bagian awal dari proses tersebut. Kota Semarang, Pekalongan, Magelang, dan Purwokerto adalah beberapa diantaranya yang sudah memiliki kesiapan insfrastruktur. Hal tersebut menjadi dasar perlu adanya rancangan strategi komunikasi yang matang sehingga mampu untuk menyampaikan pesan utama dalam proses migrasi analog ke digital sehingga berbagai stakeholder di Jawa Tengah bisa mengambil peran dan keuntungan dari proses digitalisasi ini. Penelitian ini bertujuan untuk merumuskan strategi komunikasi yang matang dalam proses sosialisasi migrasi analog ke digital di Jawa Tengah. Penyusunan strategi komunikasi didasarkan pada kebiasaan konsumsi media (audience habit) yang dilakukan oleh masyarakat Jawa Tengah. Meskipun pemerintah belum merumuskan peta jalan migrasi dengan pasti, sosialisasi tetap harus dilakukan karena proses migrasi digital adalah keniscayaan. Proses sosialisasi tetap perlu dilakukan agar pengetahuan masyarakat terhadap proses tersebut utuh. Ketika peta migrasi sudah ditetapkan maka masyarakat sudah siap karena telah dilakukan sosialisasi.

Strategi Komunikasi yang efektif didasarkan pada unsur penentu efektivitas komunikasi. Menurut Pace,dkk (1979) ada tiga tujuan utama strategi komunikasi yang ingin dicapai, yaitu (a) memastikan bahwa 
penerima pesan memahami isi pesan yang diterimanya; (b) memantapkan penerimaan pesan dalam diri penerima sasaran; (c) memotivasi kegiatan-kegiatan yang berkaitan dengan implikasi pesan.

Smith (2005) memberikan sembilan fase yang dikelompokkan menjadi empat fase dalam penyusunan komunikasi strategis untuk public relations yakni formative research, strategy, tactic dan evaluation research. Analisis tahap formative research dilakukan dengan analisis situasi, analisis organisasi, dan analisis publik. Analisis situasi adalah pernyataan tentang peluang dan hambatan yang dihadapi oleh program komunikasi. Analisis organisasi : meliputi aspek lingkungan internal, persepsi publik dan lingkungan eksternal yang dihadapi meliputi pesaing maupun pendukung. Analisis publik adalah identifikasi dan analisis publik-publik kunci dari berbagai kelompok orang yang berinteraksi dengan organisasi. Analisis strategi memiliki dua fokus yakni aksi yang dilakukan organisasi dan isi pesan. Analisis taktik terdiri dari pemilihan taktik komunikasi yang digunakan dan implementasi rencana strategis yang sudah disusun. Pada fase terakhir dilakukan evaluasi untuk mengetahui efektivitas berbagai taktik komunikasi yang digunakan untuk mencapai tujuan dan sasaran yang telah ditentukan. Pemahaman strategic communication menekankan bagaimana mengolah pesan yang tepat, menyampaikannya melalui media yang tepat, kepada audience yang tepat, pada saat yang tepat, dan efek yang diharapkan; sebuah proses yang membutuhkan pengelolaan dan kontrol secara terus-menerus. Secara ringkas gambaran dari strategi komunikasi diwujudkan dalam Communication Plan Pyramid berikut ini:

\section{Communication Plan Pyramid}

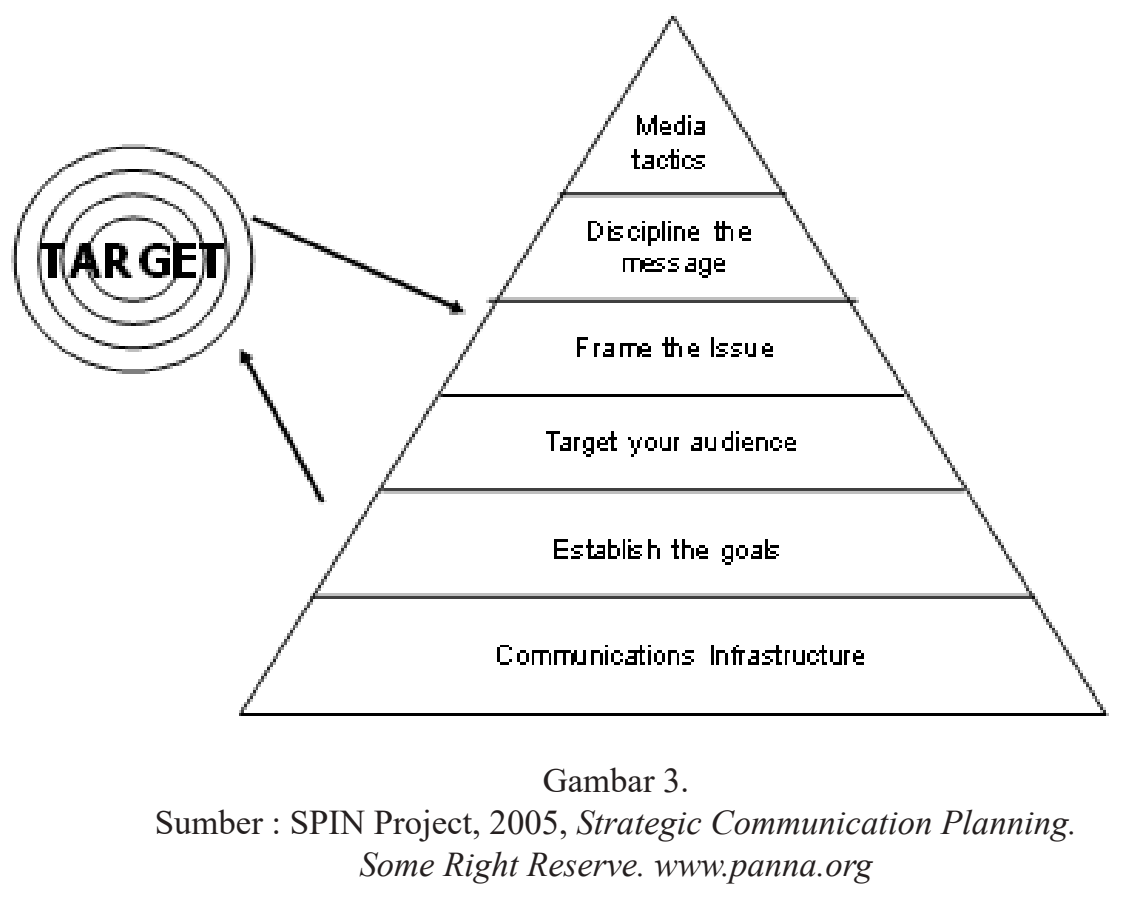


Penelitian ini bertujuan utnuk mendiskripsikan perkembangan sosialisasi, menganalisa strategi komunikasi yang digunakan dan merumuskan strategi yang tepat untuk proses sosialisasi migrasi TV analog ke digital di Jawa Tengah.

\section{Metode Penelitian}

Paradigma berfungsi sebagai seperangkat keyakinan atau basic belief systems yang mengarahkan tindakan peneliti, berkaitan dengan prinsip-prinsip utama (pokok). Paradigma penelitian ini adalah paradigma interpretif yang berbeda dengan paradigma lain dalam hal epistimologi, ontology, aksiologi, dan methodology (Guba dan Lincoln, 2005). Strategi penelitian ini adalah penelitian deskriptif kualitatif yang tidak bertujuan untuk menguji kaitan, hubungan maupun pengaruh antar variabel penelitian. Melalui strategi ini peneliti ingin mengetahui keadaan sekarang terkait pemahaman masyarakat tentang proses migrasi dan kebiasaan konsumsi media yang dijadikan dasar dalam penyusunan strategi komunikasi. Hasil penelitian Sumarsono dkk (2012) menunjukkan bahwa: masyarakat dan dunia usaha pada dasarnya telah siap menyongsong siaran televisi digital namun pemerintah masih belum cukup sosialisasi. Hasil Penelitian Prabowo dan Arofah (2017) menunjukkan tidak ada perbedaan yang signifikan antara pengetahuan sebelum menerima pesan tentang TV digital dengan setelah menerima pesan via instagram di kalangan mahasiswa.

Pada penelitian ini dipetakan kebiasaan konsumsi media dari masyarakat kemudian disusun strategi komunikasi berdasar pada kebiasaan tersebut. Teknik pengumpulan data dilakukan dengan cara wawancara. Peneliti melakukan wawancara kepada 200 orang informan yang tersebar di empat kota yaitu Semarang, Magelang, Purwokerto dan Pekalongan. Wawancara dilakukan pada bulan April- Juni tahun 2017.

Keempat kota tersebut dipilih dengan beberapa pertimbangan yaitu : mewakili Jawa Tengah bagian selatan, utara, barat, dan timur. Selain itu keempat kota tersebut juga masuk dalam rencana percontohan sosialisasi digitalisasi. Informan penelitian dipilih dari berbagai kalangan masyarakat yang mewakili akademisi, pelajar/mahasiswa, PNS, TNI/ Polri, ibu rumah tangga, pensiunan.

Peneliti juga melakukan wawancara dengan fungsionaris Komisi Penyiaran Indonesia Daerah Jawa Tengah untuk mendapatkan gambaran tentang proses sosialisasi migrasi analog ke digital di Jawa Tengah. Kedua, peneliti melakukan observasi lapangan dengan mengikuti beberapa diskusi tentang proses migrasi yang diadakan oleh mahasiswa. Tahap analisis data dilakukan dengan menggunakan analisis fase penyusunan komunikasi strategis yang meliputi formative research (riset formatif), strategy, tactic dan evaluation research (Smith, 2005).

\section{Hasil Penelitian dan Pembahasan}

Jumlah informan penelitian mencapai 200 informan dengan rincian: kota Semarang: 45 informan, Magelang: 55 informan, Purwokerto: 40 informan dan Pekalongan: 60 informan. Pada bagian pertama, peneliti akan menguraikan temuan data hasil wawancara dengan informan di empat kota dan hasil wawancara dengan komisioner KPID Jateng tentang migrasi. Pada bagian ini peneliti 
juga akan menguraikan topik-topik diskusi mahasiswa tentang proses migrasi analog ke digital yang diamati oleh peneliti.

Pertanyaan pertama yang diajukan peneliti kepada informan di empat kota adalah: apakah mereka mengetahui rencana migrasi penyiaran analog ke digital di Indonesia. Jawaban informan penelitian disajikan dalam Gambar 4.

Mayoritas informan di empat kota di Jawa Tengah menyatakan tidak tahu tentang rencana migrasi penyiaran analog ke penyiaran digital. Informan penelitian yang tahu proses migrasi adalah informan muda yang pada umumnya masih kuliah. Sedangkan bagi masyarakat di beberapa daerah proses migrasi tersebut dianggap tidak penting sehingga mereka tidak peduli. Belum adanya kepastian tentang pelaksanaan migrasi dan belum adanya sosialisasi yang massif dan terencana menjadikan masyarakat tidak mengetahui rencana migrasi tersebut. Jawa Tengah merupakan wilayah yang dekat dengan pusat pemerintahan dan didukung sarana teknologi informasi yang relatif sudah lebih maju daripada daerah lain di luar Jawa. Meskipun demikian ternyata mayoritas masyarakatnya

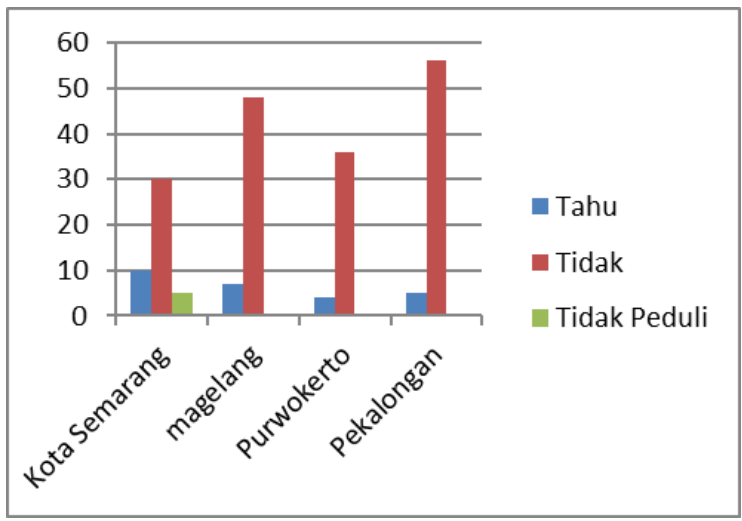

Gambar 4.

Pengetahuan Informan Tentang rencana perubahan siaran TV di Indonesia dari analog ke TV Digital Sumber : Data Peneliti 2017. belum mengetahu rencana migrasi. Informan yang mengetahui rencana migrasi adalah mahasiswa. Mereka mengetahui rencana migrasi dari berita di internet dan diskusi TV digital di beberapa kampus. Peneliti mengikuti diskusi mahasiswa Prodi Ilmu Komunikasi Unissula Semarang tentang proses migrasi. Topik yang dibicarakan adalah; kepastian migrasi, keuntungan dan kerugian masyarakat, konten digital, dan sosialisasi yang masih kurang (hasil pengamatan topik diskusi mahasiswa, Juni 2017).

Bagi informan yang tidak peduli proses migrasi dilatarbelakangi dengan beberapa alasan diantaranya: menganggap proses migrasi sebagai bagian yang tidak penting dari hidup mereka, mereka beranggapan bahwa migrasi atau tidak bukan persoalan yang harus mereka pikirkan, kehadiran internet membuat mereka tidak butuh layanan tv digital.

Mayoritas informan tidak tahu rencana migrasi penyiaran analog ke penyiaran digital. Maka dari itu sosialisasi menurut informan harus dilakukan sehingga masyarakat memahami proses tersebut. Mereka harus tahu keuntungan kerugian dari proses migrasi tersebut, kenapa migrasi harus dilakukan. Masyarakat juga melihat pentingnya sosialisasi terkait hak dan kewajiban apa yang akan mereka terima ketika proses migrasi dilakukan. Informan mengungkapkan bahwa sosialisasi bisa dilakukan dengan berbagai media baik konvensional maupun media baru seperti social media, website. Sebagian informan menjawab bahwa proses sosialisasi tidak perlu dilakukan. Jawaban ini justru muncul dari mereka yang sudah mengetahui rencana migrasi penyiaran analog ke penyiaran digital. Mereka menyatakan bahwa sosialisasi tidak 
perlu dilakukan mengingat sampai saat ini belum ada kejelasan peta jalan migrasi yang bersifat paripurna.

Hasil wawancara dengan komisioner KPID Jawa Tengah memperkuat temuan penelitian yang menunjukkan belum adanya sosialisasi yang memadai dalam proses migrasi analog ke digital di Jawa Tengah. KPID belum melakukan sosialisasi karena belum mendapatkan perintah dari KPI pusat secara kelembagaan dan belum adanya dan roadmap yang jelas tentang migrasi.
"KPID Jawa Tengah belum melakukan sosialisasi migrasi karena belum ada petunjuk dan arahan dari KPI pusat. Secara struktural kami akan mengikuti keputusan dari pusat. Sampai saat ini kepastian migrasi juga masih pembahasan, jadi mungkin KPI masih menunggu keputusan final" (hasil wawancara dengan komisioner KPID Jawa Tengah, Juni 2017).

Demi mendukung proses sosialisasi migrasi di Jawa Tengah berikut disajikan gambaran audience habit di empat kota di Jawa Tengah. Berdasar gambaran pemanfaatan media ini akan disusun strategi komunikasi yang relevan untuk sosialisasi migrasi analog ke digital di Jawa Tengah.

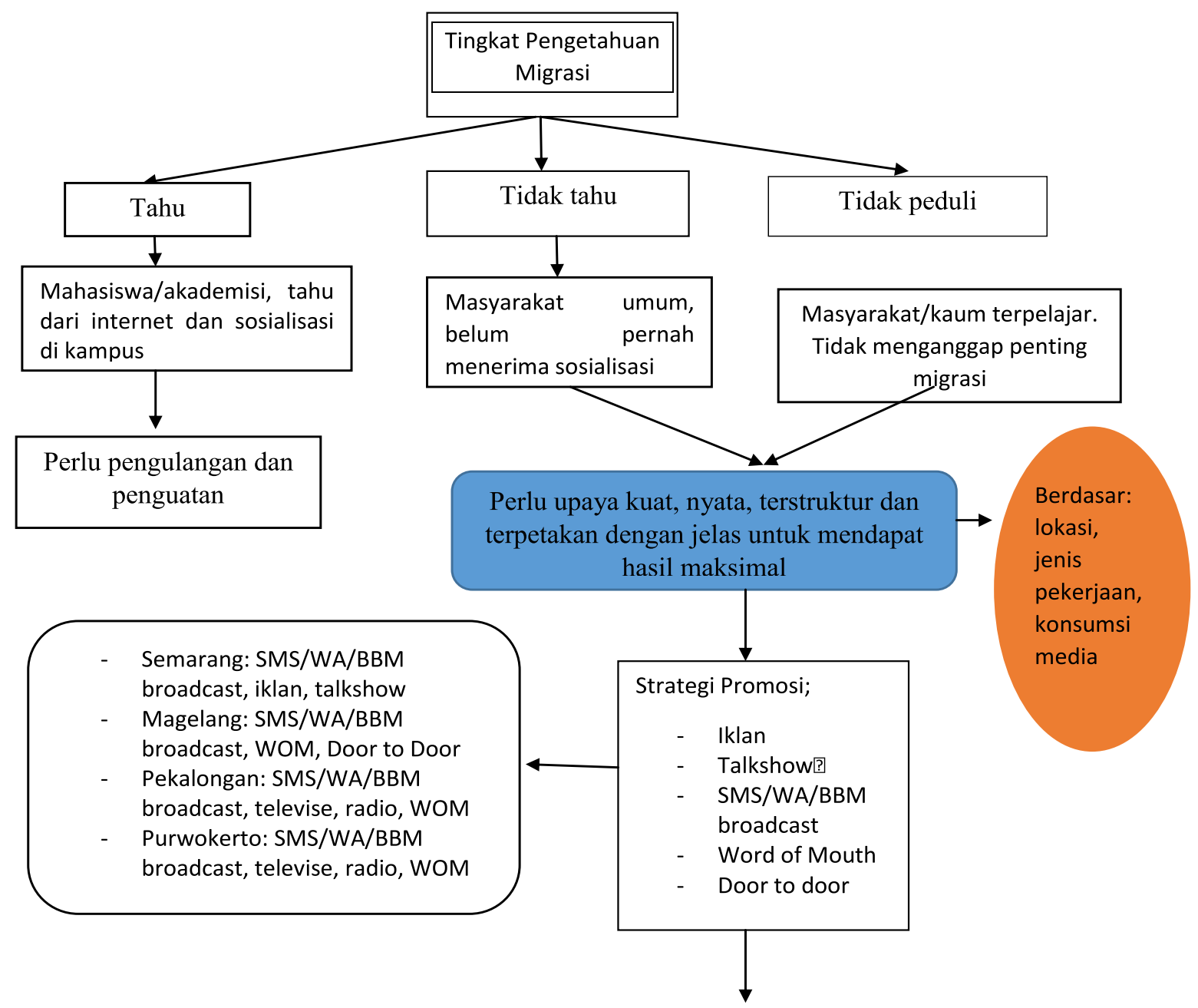

Kunci utama sosialisasi sekaligus sumber utama:

Roadmap migrasi penyiaran analog ke digital yang sudah pasti

Gambar 5. Gambaran Pemanfaatan Media di Jawa Tengah

Sumber: Ringkasan Hasil Penelitian, 2017 
Berdasarkan temuan penelitian tersebut peneliti menyusun fase strategi komunikasi untuk sosialisasi migrasi penyiaran analog ke digital di Jawa Tengah. Fase penyusunan komunikasi strategis yang meliputi formative research (riset formatif), strategy, tactic dan evaluation research. Hasil telaah riset formatif menunjukkan bahwa hambatan utama proses sosialisasi terletak pada tiga hal yaitu: mayoritas masyarakat belum tahu rencana migrasi, belum ada keputusan final tentang proses migrasi, dan ketidakpedulian sebagian masyarakat. Sementara peluang yang dimiliki adalah: gambar digital yang lebih jelas, peluang bisnis digital, peluang semakin banyaknya saluran televisi.

Masyarakat di empat kota di Jawa Tengah menghabiskan waktu lebih dari 4 jam sehari untuk menonton televisi (sumber: data hasil wawancara, 2017). Sedangkan sosial media menjadi media yang siap diakses dalam 24 jam sesuai dengan kebutuhan dari penggunanya. Sifatnya yang fleksibel dan mobilitas tinggi menjadikan sosial media diakses dalam rentang waktu yang panjang. Radio diakses dalam kurun waktu tertentu dan menyesuaikan keberadaan piranti radio di sekitar mereka. Berita di media cetak dan online dipilih oleh informan sebagai cara sosialisasi yang paling tepat untuk menjelaskan proses migrasi analog ke digital. Berita di media cetak bisa dibaca berulang dan menghasilkan kedalaman. Iklan di televisi mendapat porsi yang cukup besar untuk meningkatkan pengetahuan masyarakat. Sementara sosialisasi dari rumah ke rumah seperti halnya sensus dianggap sangat efektif untuk menjangkau masyarakat dengan tingkat pengetahuan rendah dan mereka yang kesulitan untuk mengakses media informasi. Sosialisasi dari rumah ke rumah juga membantu masyarakat untuk bertanya secara langsung kepada petugas sehingga mendapat gambaran yang jelas tentang proses migrasi.

Berdasar pada riset formatif tersebut maka disusun strategi komunikasi. Uraian strategi komunikasi terkait media sosialisasi yang digunakan dapat dilihat pada Gambar 6 dibawah ini.

Pengiriman materi sosialisasi secara massif melalui sosial media seperti whatshaps, SMS, BBM, Line merupakan cara yang cepat, dengan target luas dan murah yang bisa dilakukan untuk menyosialisasikan proses migrasi. Sosial media digunakan 24 jam oleh masyarakat. Cara ini bisa digunakan pada semua strata masyarakat di semua wilayah di Jawa Tengah. Program sosialisasi melalui televisi nasional seperti acara talkshow, iklan layanan masyarakat, testimonial juga bisa digunakan di semua wilayah karena televisi termasuk media yang diakses oleh masyarakat setiap hari. Di daerah dengan tingkat pendidikan pemilik televisi yang masih rendah sosialisasi door to door dengan kunjungan ke setiap rumah merupakan pilihan yang efektif untuk sosialisasi. Masyarakat dengan tingkat pendidikan rendah, tidak mengakses informasi secara rutin, dan kurang memahami teknologi membutuhkan penjelasan yang lebih

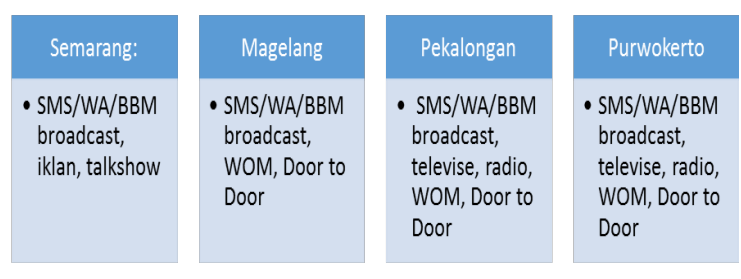

Gambar 6. Jenis Sarana Sosialisasi Yang Dipilih Masyarakat

Sumber : Data Peneliti 2017. 
daripada mereka yang aktif dan cakap dengan teknologi informasi. Masyarakat di daerah seperti Magelang, Pekalongan dan Purwokerto menghendaki adanya sosialisasi dari rumah ke rumah tentang proses migrasi analog ke digital.

Pada perjalanan proses sosialisasi masyarakat membutuhkan layanan respon yang cepat dan mudah untuk mendapatkan informasi yang utuh tentang proses migrasi. Oleh karena itu diperlukan strategi respon yang mampu menjawab kebutuhan tersebut. Perihal strategi respon bisa digunakan beberapa cara berikut, (1) Pemerintah melalui Kominfo, KPI, maupun lembaga Humas bisa membuat pusat informasi tentang proses migrasi; (2) Buat kotak pengaduan melalui sms center, email, sosial media; (3) Untuk wilayah Pekalongan, Magelang, Purwokerto dan daerah lain yang membutuhkan sosialisasi dari rumah ke rumah bisa dibentuk pusat informasi public tentang migrasi di tingkat desa. Pemerintah bisa menyediakan tenaga khusus yang mampu menjawab pertanyaan masyarakat tentang proses migrasi secara utuh.

Keberadaan pusat layanan migrasi ini bisa membantu masyarakat dengan mudah mengetahui tahapan proses migrasi yang sedang dilakukan. Persoalan utama yang harus segera diselesaikan adalah peta jalan migrasi yang bersifat paripurna dan memuat tahapan yang jelas tentang proses migrasi. Artinya semua elemen yang masih menolak dan menghambat proses migrasi harus diajak berdiskusi sehingga bisa menerima proses migrasi. Setelah proses tersebut selesai maka peta jalan migrasi akan dapat dibuat dengan paripurna sehingga memudahkan untuk menyusun strategi komunikasi yang tepat.
Strategi Komunikasi yang efektif didasarkan pada unsur penentu efektivitas komunikasi. Menurut Pace,dkk (1979) ada tiga tujuan utama strategi komunikasi yang ingin dicapai, yaitu (1) memastikan bahwa penerima pesan memahami isi pesan yang diterimanya; (2) memantapkan penerimaan pesan dalam diri penerima sasaran; (3) memotivasi kegiatankegiatan yang berkaitan dengan implikasi pesan.

Perkembangan teknologi informasi dan komunikasi di Jawa Tengah masih belum merata. Masyarakat yang tinggal di kota besar seperti Semarang, Magelang, Purwokerto, Tegal dan Pekalongan lebih beruntung daripada mereka yang tinggal di pedesaan. Gambaran ini menunjukkan bahwa secara nasionalpun kesenjangan pemanfaatan teknologi informasi masih besar. Jangankan layanan digital, tv analog pun belum bisa dirasakan di semua daerah. Masih banyak masyarakat di pedesaan yang belum bisa mengakses tv analog dengan bantuan antenna UHF. Sementara layanan internet masih terkendala dengan kesiapan infrastruktur baik listrik maupun jaringan internet.

Persoalan-persoalan tersebut harus diselesaikan sehingga strategi komunikasi yang disusun bisa dilaksanakan dengan jelas, tepat sasaran dan membawa pesan yang nyata. Berkaca dari keberhasilan beberapa negara ASEAN yang telah melakukan migrasi digital semestinya Indonesia bergerak cepat untuk melakukan migrasi. Jika proses ini berhasil maka akan mampu menghidupkan tv lokal di berbagai daerah. Kehadiran tv lokal bisa menjadi sarana untuk mengurangi dominasi siaran tv nasional 
sehingga konten lokal bisa diangkat. Jawa Tengah memiliki potensi baik ekonomi, social, seni, budaya dan beragam kearifan lokal yang bisa diangkat menjadi konten siaran. Hal tersebut bisa terwujud jika siaran tv lokal berkembang. Pemerintah bisa menempatkan Jawa Tengah sebagai salah satu daerah yang mendapatkan kesempatan migrasi lebih awal. Kesiapan infrastruktur di Jawa Tengah menjadikan daerah ini sebagai salah satu wilayah di Indonesia yang bisa dilakukan migrasi lebih cepat.

\section{Simpulan}

Penelitian ini bertujuan untuk merumuskan strategi komunikasi yang matang dalam proses sosialisasi migrasi analog ke digital di Jawa Tengah. Penyusunan strategi komunikasi didasarkan pada kebiasaan konsumsi media (audience habit) yang dilakukan oleh masyarakat Jawa Tengah. Bersarkan temuan dan pembahasan penelitian berikut simpulan penelitian; (1) Kepastian proses migrasi penyiaran analog ke penyiaran digital masih menunggu pengesahan UU Penyiaran yang baru. Jika UU tersebut bisa disahkan pada tahun 2017 maka masih ada kesempatan selama 3 tahun semenjak UU tersebut disahkan untuk melakukan migrasi. Artinya baru pada tahun 2020 proses tersebut bisa dilakukan secara tuntas. Meski demikian daerah-daerah yang sudah siap infrastruktur teknologi informasi dan komunikasinya bisa menjadi daerah yang melakukan migrasi awal. Diantara daerah yang dianggap siap untuk migrasi awal adalah Jawa Tengah. Karena itu proses sosialisasi di wilayah ini harus dilakukan dengan segera dan direncanakan dengan baik; (2) Temuan penelitian menunjukkan bahwa mayoritas masyarakat Jawa Tengah belum mengetahui rencana migrasi tersebut. Bahkan sebagian dari mereka mengaku tidak peduli dan menganggap penting proses migrasi digital. Kondisi ini menjadi tantangan untuk merencanakan strategi komunikasi yang tepat sesuai kondisi di Jawa Tengah sehingga proses migrasi bisa berjalan dengan baik dan menguntungkan semua pihak. Kepastian peta jalan migrasi yang paripurna akan memudahkan penyusunan strategi komunikasi. Langkah ini harus segera diselesaikan karena tanpa kepastian peta jalan migrasi strategi komunikasi yang disusun tida memiliki arah yang jelas sehingga sosialisasi migrasi tidak berjalan maksimal; (3) Sosialisasi tetap diperlukan meskipun peta migrasi belum dirumuskan secara pasti oleh pemerintah. Ketika pemerintah sudah menetapkan peta jalan migrasi, kondisi masyarakat sudah siap karena telah dilakukan sosialisasi sehingga proses migrasi bisa berjalan lebih cepat dan lebih baik; (4) Pemerintah harus segera menuntaskan roadmap migrasi dan menyusun strategi komunikasi untuk menyosialisasikan proses tersebut. Penyusunan strategi tersebut dimulai dari pemetaan audience habit yang kemudian menjadi dasar penyusunan strategi.

\section{Ucapan Terimakasih}

Penulis mengucapkan terimakasih kepada Direktorat Riset dan Pengabdian Masyarakat Direktorat Jenderal Penguatan Riset dan Pengembangan Kementrian Riset, Teknologi, dan Pendidikan Tinggi yang telah mendanai penelitian berjudul "Model Strategi Sosialisasi, Informasi Dan Edukasi Migrasi Sistem Penyiaran Analog Ke Digital Di Indonesia melalui skema Hibah Produk Terapan tahun 2017" yang menjadi dasar penulisan artikel 
ini. Penulis juga mengucapkan terimakasih kepada segenap jajaran LPPM Unissula Semarang dan KPID Jawa Tengah yang membantu pelaksanaan penelitian ini. Tidak lupa penulis mengucapkan terimakasih kepada segenap pihak yang membantu untuk publikasi artikel ini di Jurnal Ilmu Komunikasi Aspikom.

\section{Daftar Pustaka}

Budiarto, Hary dkk. (2007), Sistem TV DIGITAL dan Prospeknya di Indonesia. Jakarta : Multikom.

Denzin, Norman K. \& Yvonna S. Lincoln (2005). The SAGE Handbook of Qualitative Research, Third Edition. Thousand Oaks: SAGE Publications, Inc

Prabowo, Agung, Kurnia Arofah (2017). Media Sosial Instagram sebagai Sarana Sosialisasi Kebijakan Penyiaran Digital.
Yogyakarta: Jurnal Aspikom vol 3 No 2 tahun 2017.

Pace, R. Wayne et al. (1979). Techniques for effective communication. Masschusetts. Ontario: Addison Westley Publishing Company

Rianto, Puji. (2012). Dominasi TV Swasta (Nasiuonal). Tergerusnya Keberagaman Isi dan Kepemilikan. Yogyakarta: PR2Media-Yayasan Tifa. . (2012). Digitalisasi Televisi di Indonesia. Yogyakarta: PR2MediaYayasan Tifa

Smith, D. Ronald. (2005). Strategic Planning For Public Relations. Second Edition. London : Lawrence Erlbaum Associates Publisher.

SPIN Project, 2005, Strategic Communication Planning. Some Right Reserve. www. panna.org , diakses 6 Januari 2018. 